ORIGINAL RESEARCH PAPER

\title{
ANTIOXIDANT AND ANTIMICROBIAL ACTIVITIES OF HYDROPHILIC EXTRACTS FROM SHALLOT AND GARLIC BULBS, AND THEIR EFFECTS ON ROUND SCAD DURING ICED STORAGE
}

\author{
HUYNH NGUYEN DUY BAO*, PHAM THI HIEN, VU LE QUYEN \\ Faculty of Food Technology, Nha Trang University, 02 Nguyen Dinh Chieu street, Nha Trang city 650000, \\ Vietnam. \\ *Corresponding author: hndbao@ntu.edu.vn,hndbao@yahoo.com
}

Received on 27 March 2020

Revised on 22 June 2020

\begin{abstract}
The present study aimed to investigate the in vitro antioxidant and antimicrobial activities of hydrophilic extracts prepared from shallot and garlic bulbs, and their effects on round scad during iced storage. Both the shallot and garlic extracts exhibited antioxidant activity concerning DPPH radical scavenging, total reducing power, and lipid peroxidation inhibition. The extracts also had antimicrobial activity against both Gram-positive (Bacillus cereus, Staphylococcus aureus) and Gramnegative (Escherichia coli, Salmonella typhimurium) pathogenic strains. Effects of treatment with the extracts on quality of round scad were evaluated by monitoring the total lipid hydroperoxides (HPO), thiobarbituric acid reactive substances (TBARS), total volatile basic nitrogen (TVB-N), total viable counts (TVC), and sensory characteristics. The spoilage indicators (HPO, TBARS, TVB-N, TVC) of the round scad treated with either shallot or garlic extracts were significantly suppressed during the ice storage period $(\mathrm{P}<0.05)$. Round scad treated with either shallot or garlic extracts kept their natural sensory characteristics accepted for food-grade longer than 4 days of ice storage, compared with the control (without treatment). These results clearly show that the shallot and garlic extracts are potential natural preservatives, which can extend shelf-life of iced round scad.
\end{abstract}

Keywords: antimicrobial activity, lipid oxidation, natural antioxidant, fish spoilage; spices

\section{Introduction}

In recent years, consumers tend to eat fresh fish rather than processed or frozen ones, while the shelf-life of fresh fish is normally short. The spoilage of fresh fish is mainly due to enzymatic autolysis, microbial growth, and lipid oxidation, and thus limiting the shelf-life. It drastically reduces the product-market value, leading

https://doi.org/10.35219/foodtechnology.2020.1.02 
to considerable financial loss. To extend the shelf-life of fresh fish, the use of preservatives has been believed traditionally to be virtually the only efficacious way. However, the improper use of preservatives can lead to harmful effects on human health (Amit et al., 2017). For this reason, the use of natural preservatives should be a promising designation to extend the shelf-life of fresh fish, thereby minimizing economic loss.

Scad (Decapterus ssp.) is a coastal pelagic fish found in the Pacific, Atlantic, and Indian Oceans. The species are substantial sources of food and thus play an important role in the economy of many countries. Scad lipids contain a significant amount of polyunsaturated omega-3 fatty acids (PUFAs) which have been reported to have positive effects on various cardiovascular diseases, including blood clotting and high blood pressure (Metillo and Aspiras-Eya, 2014; Shahidi and Ambigaipalan, 2018). However, because of the presence of PUFAs, the lipids are highly vulnerable towards oxidation. Lipid oxidation is one of the major causes of spoilage of fish and has a detrimental effect on colour, flavour, texture and nutritional value (Bao and Ohshima, 2014). On the other hand, decreased nutritional value, changed texture, discolouration, and off-odour development in fish may also result from bacterial growth (Kuley et al., 2017; Odeyemi et al., 2018). Hence, bacterial growth and lipid oxidation are processes that restrict the shelf-life of fish.

Natural preservatives generally originate from microorganisms, plants, and animals. Mei et al. (2019) suggested that plant extracts might have broad application prospects in the preservation of fish. Numerous in vitro studies have been conducted to evaluate the antioxidant and antimicrobial activities of plant extracts. However, only a few studies have been carried out to assess the antioxidant and antimicrobial activities of plant extracts in fish preservation (Pezeshk et al., 2015; Olatunde and Benjakul, 2018; Gokoglu, 2019). Plant extracts for food application are customarily prepared from fruits, vegetables, and other edible natural materials (Sultanbawa, 2014; Weng and Yen, 2015; Gyawali et al., 2015; Pabón-Baquero et al., 2018; Chibane et al., 2019). Among them, the extracts prepared from shallot and garlic bulbs show potential for antioxidant and antimicrobial activities in vitro and applicable competency in vivo (Pezeshk et al., 2011; Pezeshk et al., 2013; Viswanathan et al., 2014; Mozin et al., 2015; Raeisi et al., 2016; Octaviani et al., 2019). Both shallot and garlic are known to have dietary and therapeutic benefits (Santhosha et al., 2013; Bisen and Emerald, 2016; Zeng et al., 2017). However, many studies were conducted to extract natural bioactive compounds using organic solvents (Viswanathan et al., 2014; Charoenchai et al., 2017; Kang et al., 2018; Octaviani et al., 2019; Thuy et al., 2020). Researchers and experts have considered the environmental impact of using organic solvents to extract natural bioactive compounds to be severe. They are also concerned with residual organic solvent in extracts to contaminate food with added the extracts. The latest development in extraction techniques mainly focuses on finding solutions to minimize the use of organic solvents (Chemat et al., 2012; Tiwari, 2015; McDonnell and Tiwari, 2017). Our previous studies have successfully prepared hydrophilic extracts of shallot and 
garlic bulbs using ultrasound-assisted extraction technology (Bao et al., 2017; Phuong and Bao, 2020). The present study was therefore conducted to evaluate the antioxidant and antimicrobial activities of these extracts in vitro and their effects on round scad during iced storage.

\section{Materials and methods}

\section{Chemicals}

Thiobarbituric acid was obtained from Wako (Wako Pure Chemical Industries, Ltd., Osaka, Japan). All other chemicals were of analytical grade and were obtained from Sigma-Aldrich (Sigma Chemical Co., St. Louis, MO, USA).

\section{Preparation of shallot and garlic extracts}

Shallot (Allium ascalonicum) and garlic (Allium sativum) bulbs were purchased from BigC supermarket in Nha Trang, Vietnam. Shallot and garlic extracts were prepared by adapting our previously developed procedure (Bao et al., 2017; Phuong and Bao, 2020). The bulbs of shallot or garlic were individually ground with a Panasonic blender model MX-GM1011 (Panasonic Malaysia), and $100 \mathrm{~g}$ of the ground material was separately extracted with $1 \mathrm{~L}$ of double-distilled water at $30 \pm 2{ }^{\circ} \mathrm{C}$ for $15 \mathrm{~min}$ by ultrasound-assisted extraction technology (frequency 20 $\mathrm{kHz}$ ). The extract was collected by centrifuging the mixture at $3.000 \times \mathrm{g}$ for $15 \mathrm{~min}$ at $4{ }^{\circ} \mathrm{C}$ and was then filtered through a Whatman grade 1 filter paper.

\section{Treatment of fish with the extracts}

Round scad (Decapterus maruadsi, 90 - 110 g body weight and $17-20 \mathrm{~cm}$ fork length) were purchased from Vinh Luong Fishing Port (Nha Trang, Vietnam). The fish was kept on ice in a Styrofoam box and transported to the laboratory at Nha Trang University. The fish was washed quickly with cold tap water $\left(<4^{\circ} \mathrm{C}\right)$ within 30 sec to remove any sand and other foreign matter, and was then drained on the screen for $3 \mathrm{~min}$ at $4^{\circ} \mathrm{C}$. Subsequently, the fish was immersed in either shallot or garlic extracts using a fish/extract ratio of $5 / 1.5(\mathrm{w} / \mathrm{v})$ at $2-4^{\circ} \mathrm{C}$ for $10 \mathrm{~min}$. The control fish immersed in double-distilled water at a ratio of $5 / 1.5(\mathrm{w} / \mathrm{v})$ for $10 \mathrm{~min}$ at $2-4^{\circ} \mathrm{C}$. All samples were stored in a styrofoam box containing ice using a fish/ice ratio of 1:2 $(\mathrm{w} / \mathrm{w})$. To maintain the fish/ice ratio, the molten ice was removed and replaced with an equal amount of ice.

\section{Measurement of 2,2-diphenyl-1-picrylhydrazyl radical scavenging activity}

2,2-Diphenyl-1-picrylhydrazyl (DPPH) radical scavenging activity was measured using the method of Fu et al. (2002) with a slight modification. Briefly, a $0.5 \mathrm{~mL}$ portion of $0.1 \mathrm{mM}$ DPPH methanol solution was mixed with different volumes of extracts ranging from 0.2 to $0.5 \mathrm{~mL}$, each of which was increased to a final volume of $3 \mathrm{~mL}$ by the addition of methanol. The mixtures were held in the dark at $25^{\circ} \mathrm{C}$ for $30 \mathrm{~min}$. Butylated hydroxytoluene (BHT) was used as a positive standard. The absorbance of the mixtures was measured at $517 \mathrm{~nm}$ against a control without DPPH using a Biochrom Libra S50 UV/VIS spectrophotometer (Cambridge, UK). A calibration curve was acquired by measuring various concentrations of the authentic DPPH standard. The DPPH radical scavenging activity was expressed as millimoles of DPPH scavenged. 


\section{Measurement of total reducing power ability}

Total reducing power ability was measured using the method of Oyaizu (1986) with a slight modification. Briefly, a $0.5 \mathrm{~mL}$ portion of $1 \%$ potassium ferricyanide was mixed with different volumes of extracts ranging from 0.2 to $0.5 \mathrm{~mL}$, each of which was increased to a final volume of $1.5 \mathrm{~mL}$ by the addition of $0.2 \mathrm{M}$ sodium phosphate buffer ( $\mathrm{pH} 6.6$ ). The mixtures were kept at $50^{\circ} \mathrm{C}$ for $20 \mathrm{~min}$, and then 0.5 $\mathrm{mL}$ of $10 \%$ trichloracetic acid was added. Subsequently, $2 \mathrm{~mL}$ of distilled water was added, followed by the addition of $400 \mu \mathrm{L}$ of $0.1 \%$ ferric chloride. BHT was used as a positive standard. The absorbance of the mixtures was measured at 700 $\mathrm{nm}$ against a control, without the extracts, using the spectrophotometer. A calibration curve was acquired by measuring various concentrations of the authentic L-ascorbic acid standard. All data were expressed as milligrams of Lascorbic acid per millilitre of the extracts.

\section{Measurement of lipid peroxidation inhibitory activity}

Lipid peroxidation inhibitory activity was measured following the method of Bao et al. (2014). Briefly, the reaction mixture $(0.5 \mathrm{~mL})$ containing $0.1 \mathrm{~mL}$ of $50 \mu \mathrm{M}$ metmyoglobin in phosphate buffer (50 mM, pH 7.4), $0.1 \mathrm{~mL}$ of $100 \mu \mathrm{M} \mathrm{H}_{2} \mathrm{O}_{2}$ in phosphate buffer $(50 \mathrm{mM}, \mathrm{pH} 7.4), 0.2 \mathrm{~mL}$ of $50 \mu \mathrm{M}$ eicosapentaenoic acid in Tween $20,0.1 \mathrm{~mL}$ of the extract was incubated at $37^{\circ} \mathrm{C}$ for $30 \mathrm{~min}$. BHT was used as a positive standard. Thiobarbituric acid reactive substances (TBARS) formations in the incubation mixture were determined spectrophotometrically according to the procedure of Uchiyama and Mihara (1978).

\section{Evaluation of antibacterial activity}

Antibacterial activity was evaluated using the well diffusion method on Trypticase soy agar (TSA). Four species of foodborne pathogenic bacteria were used as references for the antibacterial assay of the extracts, including Bacillus cereus, Escherichia coli, Salmonella typhimurium, and Staphylococcus aureus. All tested microorganisms were supplied by the Microbiology Laboratory, Center for Experiments and Practices, Nha Trang University. Briefly, TSA agar plates were inoculated with bacterial strain under aseptic conditions, and wells (diameter $=$ $5 \mathrm{~mm}$ ) were filled with $30 \mu \mathrm{l}$ of the extracts or $30 \mu \mathrm{l}$ of double-distilled water for control. The plates were incubated at $37^{\circ} \mathrm{C}$ for 24 hours under aerobic conditions. After the incubation period, the diameter of the growth inhibition zone around the wells was measured. The inhibition zones were reported in millimetres ( $\mathrm{mm}$ ).

\section{Measurement of total phenolic compounds}

The total amount of phenolic compounds was quantitatively measured following the description of $\mathrm{Fu}$ et al. (2002). The reaction mixture containing $4 \mathrm{~mL}$ of $10 \%$ aqueous Folin-Ciocalteu reagent solution, $0.2 \mathrm{~mL}$ of the extracts, and $0.8 \mathrm{~mL}$ distilled water was mixed thoroughly in a test tube. Subsequently, $5 \mathrm{~mL}$ of $7.5 \%$ sodium carbonate solution in distilled water was added, followed by the incubation at $25^{\circ} \mathrm{C}$ for $30 \mathrm{~min}$. The absorbance of the mixture was measured with the spectrophotometer at $765 \mathrm{~nm}$ against a control without the extracts. A calibration curve was acquired by measuring various concentrations of the authentic gallic 
acid standard. All data were expressed as milligrams of gallic acid per millilitre of the extracts.

\section{Measurement of total lipid hydroperoxides}

Total lipid hydroperoxides were measured according to the procedure of Shantha and Decker (1994) with a slight modification. Briefly, lipids were extracted from 5 $\mathrm{g}$ of minced fish muscle following the method of Bligh and Dyer (1959). The filtrate obtained was raised to a final volume of $10 \mathrm{~mL}$ by addition of chloroform/methanol (2/1). Subsequently, $50 \mu \mathrm{L}$ of $30 \%$ ammonium thiocyanate solution was added, following by the addition of $50 \mu \mathrm{L}$ of $2 \%$ ferrous chloride solution. The mixture was vortexed for $2-4 \mathrm{~s}$ and then incubated at room temperature for $5 \mathrm{~min}$. The absorbance of the mixture was measured at $500 \mathrm{~nm}$ against a blank without the sample using the spectrophotometer. A calibration curve was acquired by measuring various concentrations of the authentic cumene hydroperoxide standard. All data were expressed as nmol of cumene hydroperoxide per gram of the fish muscle.

\section{Measurement of thiobarbituric acid reactive substances}

Thiobarbituric acid reactive substances (TBARS) were measured following the method of Uchiyama and Mihara (1978). Briefly, $0.5 \mathrm{~g}$ of the minced fish meat was homogenized with $4.5 \mathrm{~mL}$ of $1.15 \% \mathrm{KCl}$ solution. The reaction mixture containing $0.5 \mathrm{~mL}$ of the homogenate, $0.3 \mathrm{~mL}$ of $1 \%$ phosphoric acid, and $1.0 \mathrm{~mL}$ of $0.6 \% 2$-thiobarbituric acid solution was mixed thoroughly in a screw-capped test tube. The mixture was subsequently incubated at $95{ }^{\circ} \mathrm{C}$ for $45 \mathrm{~min}$ using a water bath. After cooling to ambient temperature, $4.0 \mathrm{~mL}$ n-butanol was added to the test tube. The tube was vortexed and then centrifuged at $3000 \mathrm{rpm}$ for $10 \mathrm{~min}$. The absorbances of the mixture were measured at $535 \mathrm{~nm}$ and $520 \mathrm{~nm}$ against a blank without the sample using the spectrophotometer. The TBARS value was calculated using the difference between absorbances at $535 \mathrm{~nm}$ and $520 \mathrm{~nm}$. A calibration curve was acquired by measuring various concentrations of the authentic 1,1,3,3'-tetraethoxypropane standard. The TBARS values are expressed in terms of malondialdehyde (MDA) equivalents.

\section{Measurement of total volatile basic nitrogen}

Total volatile basic nitrogen (TVB-N) was measured according to described in the Commission Regulation (EC) No 2074/2005 of 5 December 2005, Chapter III, "Determination of the concentration of TVB-N in fish and fishery products" (2005).

\section{Determination of total viable count}

The fillets with skin were separated from whole round scad and minced under aseptic conditions. A portion of $25 \mathrm{~g}$ the minced fish was mixed with $225 \mathrm{~mL}$ of sterilized saline peptone solution $(0.1 \% \mathrm{w} / \mathrm{v}$ peptone, $0.9 \% \mathrm{w} / \mathrm{v} \mathrm{NaCl})$ in a stomacher for one minute. Successive 10-fold dilutions were made as required. Total viable count (TVC) was performed on Plate Count Agar (Merck, Germany) incubated at $30^{\circ} \mathrm{C}$ for $72 \mathrm{~h}$ according to ISO 4833-2 (2013). The results are 
expressed as decimal logarithmic average values of colony-forming units per gram $(\log \mathrm{cfu} / \mathrm{g})$.

\section{Sensory evaluation}

Sensory quality of round scad was evaluated according to the sensory scheme (Table 1) for bluefish described in the Council Regulation (EC) No 2406/96 of 26 November 1996 (1996) using a five-member panel. Panelists were trained to assess according to a scale from 0 to 3 , in which a score of 2.7 to $3.0=$ extra quality (E); a score of 2.0 to 2.6 = good quality (A); a score of 1.0 to 1.9 = fair quality (B); a score of 0.0 to $0.9=$ poor quality (not admitted).

Table 1. EU scheme for the sensory evaluation of bluefish freshness.

\begin{tabular}{|c|c|c|c|c|}
\hline \multirow{3}{*}{$\begin{array}{l}\text { Parts of } \\
\text { fish } \\
\text { inspected }\end{array}$} & \multicolumn{4}{|c|}{ Criteria } \\
\hline & \multicolumn{3}{|c|}{ Freshness category } & \multirow{2}{*}{$\begin{array}{c}\text { Not } \\
\text { admitted }\end{array}$} \\
\hline & $\mathbf{E}$ & $\mathbf{A}$ & B & \\
\hline Skin & $\begin{array}{l}\text { Bright pigmentation, } \\
\text { bright, shining } \\
\text { Iridescent colours; } \\
\text { clear distinction } \\
\text { between dorsal } \\
\text { and central } \\
\text { surfaces }\end{array}$ & $\begin{array}{l}\text { Loss of lustre } \\
\text { and shine; } \\
\text { duller } \\
\text { colours; less } \\
\text { difference } \\
\text { between dorsal } \\
\text { and ventral } \\
\text { surfaces }\end{array}$ & $\begin{array}{l}\text { Dull, lustreless, } \\
\text { insipid colours; } \\
\text { skin creased } \\
\text { when fish } \\
\text { curved }\end{array}$ & $\begin{array}{l}\text { Very dull } \\
\text { pigmentati } \\
\text { on; skin } \\
\text { coming } \\
\text { away from } \\
\text { flesh }\end{array}$ \\
\hline Skin mucus & $\begin{array}{l}\text { Aqueous, } \\
\text { transparent }\end{array}$ & Slightly cloudy & Milky & $\begin{array}{l}\text { Yellowish } \\
\text { grey, } \\
\text { opaque } \\
\text { mucus }\end{array}$ \\
\hline $\begin{array}{l}\text { Consistency } \\
\text { of flesh }\end{array}$ & Very firm, rigid & $\begin{array}{l}\text { Fairly rigid, } \\
\text { firm }\end{array}$ & Slightly soft & $\begin{array}{l}\text { Soft } \\
\text { (flaccid) }\end{array}$ \\
\hline Gill covers & Silvery & $\begin{array}{l}\text { Silvery, slightly } \\
\text { red or brown }\end{array}$ & $\begin{array}{l}\text { Brownish and } \\
\text { extensive } \\
\text { seepage of blood } \\
\text { from vessels }\end{array}$ & Yellowish \\
\hline Eye & $\begin{array}{l}\text { Convex, } \\
\text { bulging; blueblack } \\
\text { bright } \\
\text { pupil, } \\
\text { transparent } \\
\text { 'eyelid' }\end{array}$ & $\begin{array}{l}\text { Convex and } \\
\text { slightly sunken; } \\
\text { dark pupil; } \\
\text { slightly } \\
\text { opalescent } \\
\text { cornea }\end{array}$ & $\begin{array}{l}\text { Flat; blurred } \\
\text { pupil; blood } \\
\text { seepage around } \\
\text { the eye }\end{array}$ & $\begin{array}{l}\text { Concave } \\
\text { in the } \\
\text { centre; } \\
\text { grey pupil; } \\
\text { milky } \\
\text { cornea }\end{array}$ \\
\hline Gills & $\begin{array}{l}\text { Uniformly dark } \\
\text { red to purple. } \\
\text { No mucus }\end{array}$ & $\begin{array}{l}\text { Less bright } \\
\text { colour, paler at } \\
\text { edges. } \\
\text { Transparent } \\
\text { mucus }\end{array}$ & $\begin{array}{l}\text { Becoming thick } \\
\text { discoloured } \\
\text { opaque mucus }\end{array}$ & $\begin{array}{l}\text { Yellowish; } \\
\text { milky } \\
\text { mucus }\end{array}$ \\
\hline $\begin{array}{l}\text { Smell of } \\
\text { gills }\end{array}$ & $\begin{array}{l}\text { Fresh seaweed; } \\
\text { pungent; iodine }\end{array}$ & $\begin{array}{l}\text { No smell or } \\
\text { seaweed. } \\
\text { Neutral smell }\end{array}$ & $\begin{array}{l}\text { Slightly } \\
\text { Sulphureous fatty } \\
\text { smell, rancid bacon } \\
\text { cuttings or rotten } \\
\text { fruit }\end{array}$ & $\begin{array}{l}\text { Rotten } \\
\text { sour }\end{array}$ \\
\hline
\end{tabular}




\section{Statistical analyses}

All the experiments were performed in triplicates. Means and standard deviations for all multiple measurements were calculated using Microsoft Excel 2013. Statistical difference between the samples at $p<0.05$ was determined by a one-way ANOVA and Tukey's Multiple Comparisons of Means using R software version 3.5.2 (http://cran.R-project.org).

\section{Results and discussion}

DPPH radical scavenging activity, total reducing power ability, and total phenolic compounds

DPPH radical scavenging activity (RSA) and total reducing power ability (RPA) of BHT and the extracts prepared from the shallot and garlic bulbs with different amounts are presented in Figure 1.
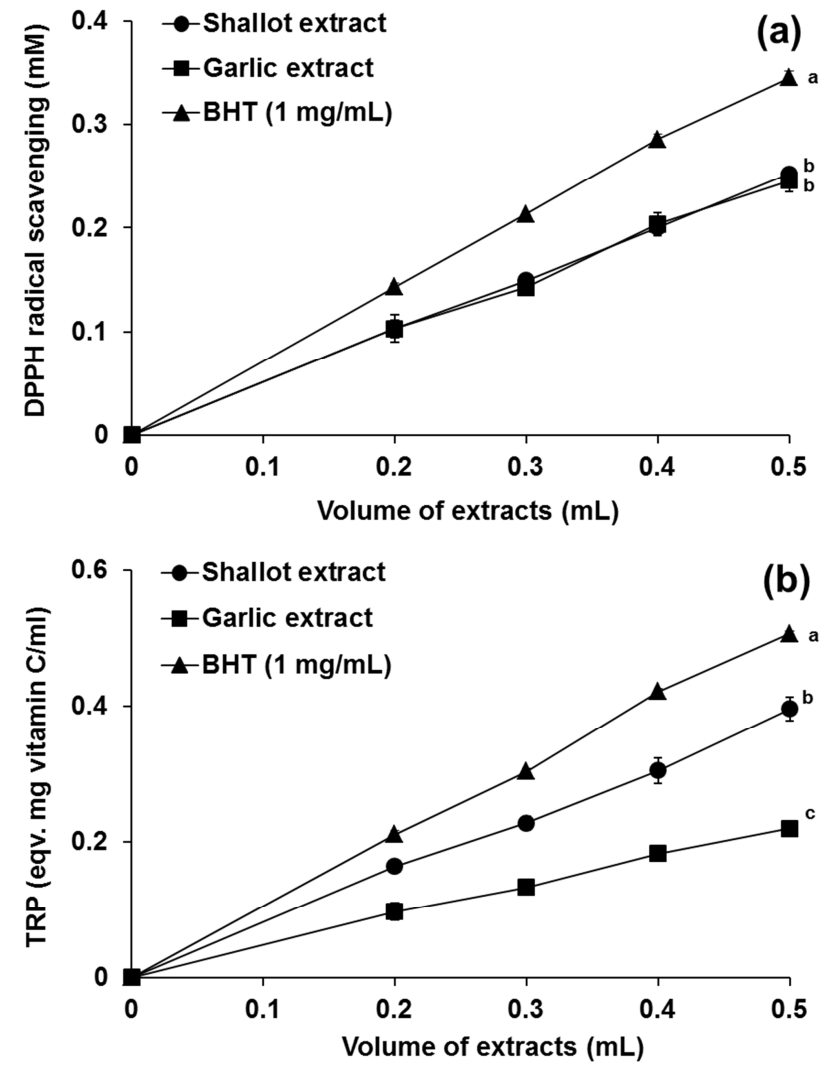

Figure 1. DPPH radical scavenging activity (a) and total reducing power ability (b) of butylated hydroxytoluene (BHT) and extracts prepared from the shallot and garlic bulbs. Data are presented as mean $\pm \mathrm{SD}(\mathrm{n}=3)$. Values with different superscript letters represent a significant difference $(\mathrm{p}<0.05)$. 
The amounts of the extracts in the reaction mixtures ranged from 0.2 to $0.5 \mathrm{~mL}$. It is evident that, in general, both the extracts displayed increased RSA and RPA by their amounts in the reaction mixture. There was no significant difference ( $p>$ 0.05 ) between these two extracts with respect to RSA (Figure 1a). However, the RPA of shallot extract was higher $(p<0.05)$ than that of garlic extract at the same concentration (Figure1b). Both RSA and RPA of the extracts were significantly lower $(\mathrm{p}<0.05)$ than that of BHT $(1 \mathrm{mg} / \mathrm{mL})$ at the same volume.

Antioxidant activity of extracts from shallot and garlic has been investigating by many researchers (Benkeblia, 2005; Leelarungrayub et al., 2006; Othman et al., 2008; Chaithradhyuthi et al., 2009; Rahman et al., 2012; Bisen and Emerald, 2016). The antioxidant activity was largely contributed by the phenolic compounds (Bozin et al., 2008), especially quercetin presented in the shallot extract (Pudzianowska et al., 2012; Thuy et al., 2020) and phenolic acids presented in the garlic extract (Beato et al., 2011; Drozd et al., 2011). The results obtained in the present study showed that the concentrations of total phenolic compounds in shallot and garlic extracts were $8.82 \pm 0.06 \mu \mathrm{g} / \mathrm{mL}$ and $14.20 \pm 0.07 \mu \mathrm{g} / \mathrm{mL}$, respectively.

\section{Lipid peroxidation inhibitory activity}

Percentage inhibition of lipid peroxidation by BHT and the extracts prepared from the shallot and garlic bulbs are presented in Figure 2. Both the extracts inhibited more than $80 \%$ of lipid peroxidation in the reaction mixtures.

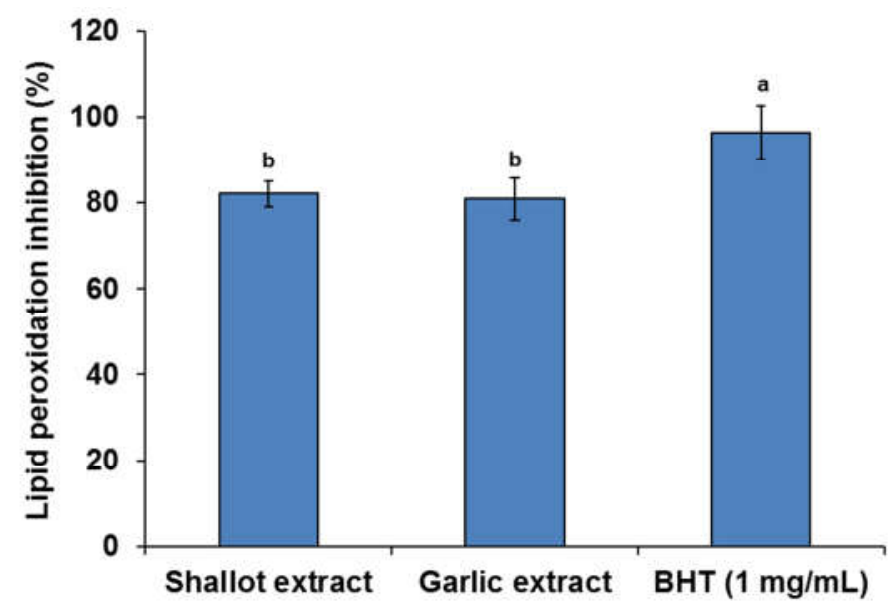

Figure 2. Lipid peroxidation inhibitory activity of butylated hydroxytoluene (BHT) and extracts prepared from the shallot and garlic bulbs. Data are presented as mean $\pm S D(n=3)$. Values with different superscript letters represent a significant difference $(p<0.05)$.

Nuutila et al. (2003) reported that extracts from onion and garlic inhibited lipid peroxidation, and the inhibitory activity correlated positively with the radical scavenging activity of these extracts. The present study found that there was no 
significant difference $(p>0.05)$ between the shallot and garlic extracts concerning the lipid peroxidation inhibitory activity. The lipid peroxidation inhibitory activity of the extracts was lower $(\mathrm{p}<0.05)$ than that of BHT $(1 \mathrm{mg} / \mathrm{mL})$ at the same volume. These results confirm a positive correlation between lipid peroxidation inhibitory activity and radical scavenging activity of the extracts.

\section{Antimicrobial activity}

The antimicrobial activity of extracts prepared from the shallot and garlic bulbs against pathogenic bacteria is presented in Figure 3. The results showed that the extracts have antimicrobial activity against both Gram-positive (Bacillus cereus, Staphylococcus aureus) and Gram-negative (Escherichia coli, Salmonella typhimurium) pathogenic strains. Some researchers investigated the antimicrobial activity of shallot and garlic extracts (Chaithradhyuthi et al., 2009; Amin et al., 2009; Viswanathan et al., 2014; Saenthaweesuk et al., 2015). The major active compounds were essential oils, organosulfur and phenolic compounds (Benkeblia, 2004; Benkeblia et al., 2005; Block, 2010), especially allicin presented in the garlic extract (Ankri and Mirelman, 1999; Rahman, 2007). The present study has shown that the antimicrobial activity of garlic extract was significantly higher $(\mathrm{p}<0.05)$ than those of shallot extract. This may probably be due to the garlic extract containing a certain amount of allicin which actively inhibits a wide range of Gram-negative and Gram-positive bacteria (Ankri and Mirelman, 1999).

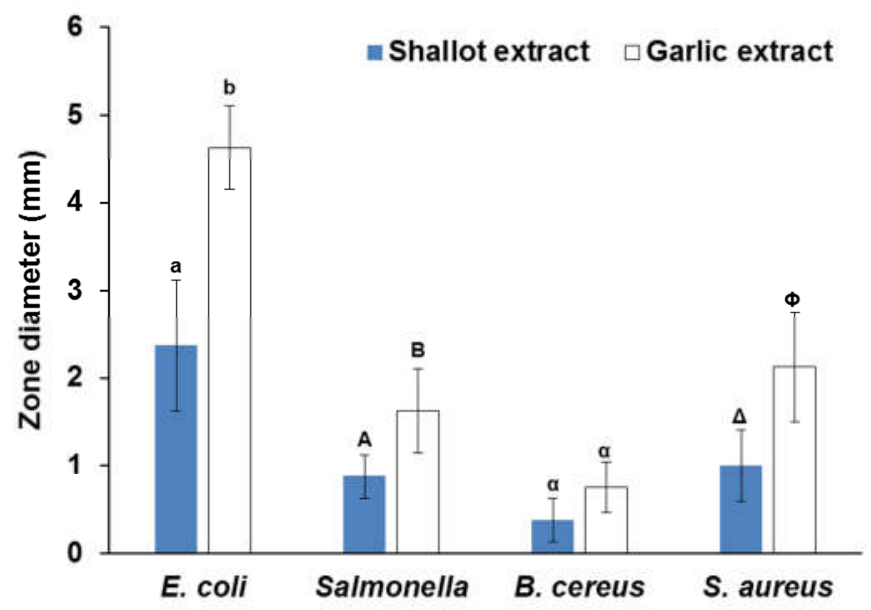

Figure 3. Antimicrobial activity of extracts prepared from the shallot and garlic bulbs. Data are presented as mean $\pm \mathrm{SD}(\mathrm{n}=3)$. Values with different superscript letters represent a significant difference $(\mathrm{p}<0.05)$.

\section{Chemical, microbiological and sensory changes of round scad stored in ice}

Changes in total lipid hydroperoxides (HPO) and thiobarbituric acid reactive substances (TBARS) of round scad with treated shallot extract, garlic extract, and control during ice storage are presented in Figure 4. 

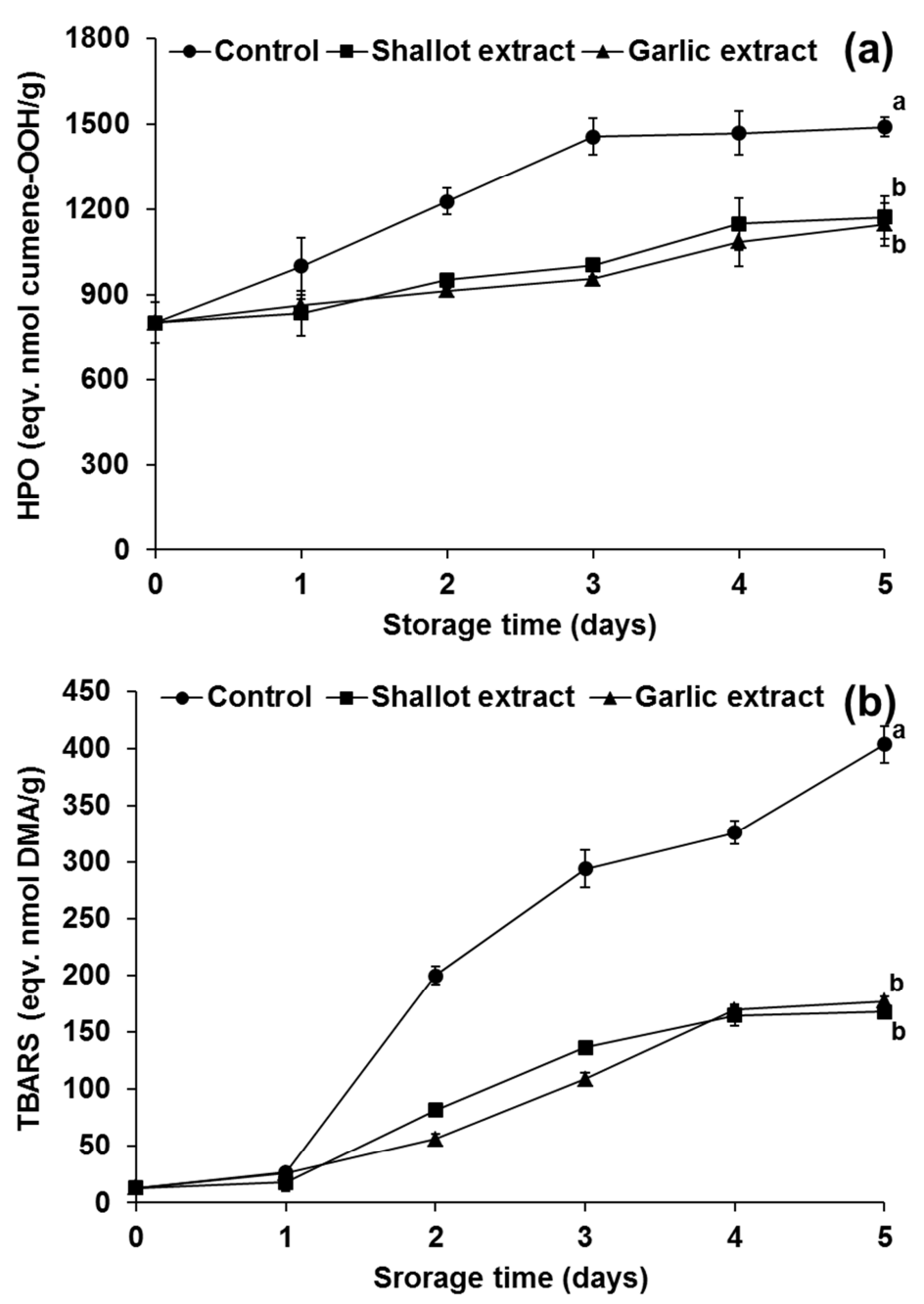

Figure 4. Changes in total lipid hydroperoxides (HPO, a) and thiobarbituric acid reactive substances (TBARS, b) of round scad during iced storage. (घ), The round scad was immersed in shallot extract; $(\boldsymbol{\Delta})$, The round scad was immersed in garlic extract; $(\bullet)$, The round scad was immersed in distilled water. Data are presented as mean $\pm \operatorname{SD}(n=3)$. Values with different superscript letters represent a significant difference $(p<0.05)$.

The induction period of lipid oxidation in the muscle of round scad with treated shallot extract or garlic extract was prolonged significantly as shown in Figure 4a. Meanwhile, the accumulated amount of HPO in the muscle of fish with treated shallot extract or garlic extract was significantly $(\mathrm{p}<0.05)$ suppressed after 3 days of ice storage, while the HPO in the muscle of control fish increased significantly $(p<0.05)$ after one day under similar storage conditions. Rancid odor development has a significant correlation with the HPO content of fish muscle during post- 
mortem storage and HPO at a higher level of $1500 \mathrm{nmol} / \mathrm{g}$ was noted rancid odor development (Sohn et al., 2005). The present study showed that the accumulated amount of HPO in the muscle of round scad with treated either shallot or garlic extracts was virtually controlled below the level of $1200 \mathrm{nmol} / \mathrm{g}$ of fish muscle after 5 days of ice storage.

The accumulated amount of TBARS in the muscle of all round scad increased significantly after 1 day of ice storage (Figure $4 \mathrm{~b}$ ). However, the TBARS value of fish in the control group was significantly $(\mathrm{p}<0.05)$ higher than that in the shallot extract group and the garlic extract group during 5 days of ice storage. TBARS were measured as an indicator of secondary lipid oxidation products. The scad contains highly polyunsaturated fatty acid (Hale, 1984; Metillo and Aspiras-Eya, 2014) and the improper handling after harvesting can induce lipid oxidation. The onset of lipid oxidation in fish leads to a loss of quality. The loss of quality is usually evident in the later stages of lipid oxidation and is associated with the characteristics of flavour, colour, texture, and nutritional value (Bao and Ohshima, 2013). Therefore, the shelf-life of fresh fish is limited. Previous studies reported that TBARS values have a correlation with sensory assessments (Hoyland and Taylor, 1991; Raharjo et al., 1993), fish with TBARS above the level of $200 \mathrm{nmol}$ MDA/g will probably have rancid odours (Ke et al., 1976). The present study found that the immersing round scad in either shallot or garlic extracts kept the TBARS content of the treated fish below the level of $200 \mathrm{nmol} \mathrm{MDA} / \mathrm{g}$ after 5 days of ice storage.

Changes in total volatile basic nitrogen (TVB-N) of round scad with treated shallot extract, garlic extract, and control during ice storage are presented in Figure 5.

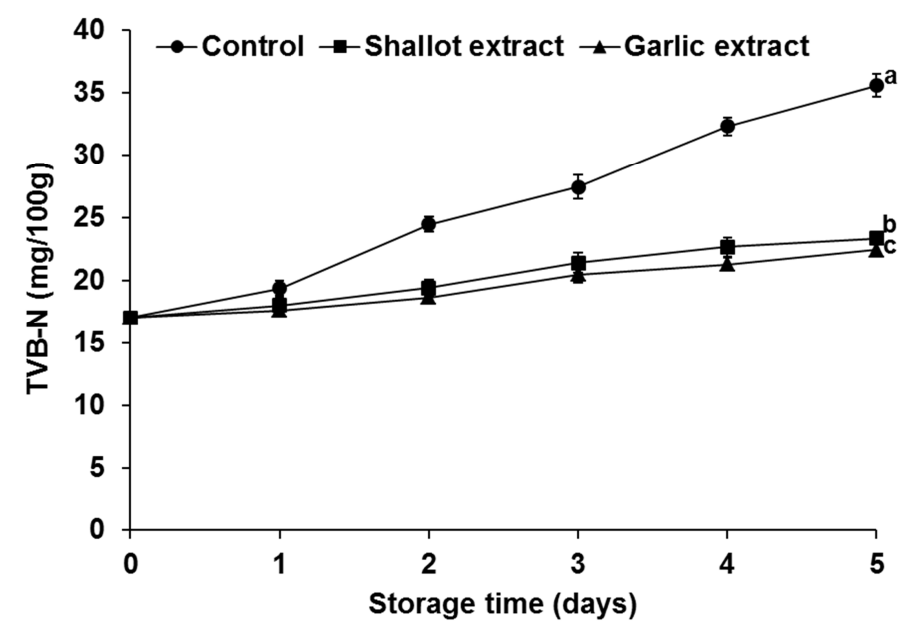

Figure 5. Changes in total volatile basic nitrogen (TVB-N) of round scad during iced storage. ( $\boldsymbol{\square})$, The round scad was immersed in shallot extract; $(\boldsymbol{\Delta})$, The round scad was immersed in garlic extract; $(\bullet)$, The round scad was immersed in distilled water. Data are presented as mean $\pm \mathrm{SD}(\mathrm{n}=3)$. Values with different superscript letters represent a significant difference $(\mathrm{p}<0.05)$. 
TVB-N is one of the most widely used measurements of the fresh fish quality because the increased TVB-N value is related to the activity of endogenous enzymes and the growth of spoilage bacteria (Howgate, 2010a; Howgate, 2010b). The increase in TVB-N in the muscle of round scad with treated either shallot or garlic extracts remarkably retarded after 5 days of ice storage, while the TVB-N in the muscle of control fish increased significantly $(\mathrm{p}<0.05)$ after one day under similar storage conditions (Figure 5). The limit of TVB-N for fresh fish is $25 \mathrm{mg}$ $\mathrm{N} / 100 \mathrm{~g}$ of fish muscle (Connell, 1990). In the present study, the TVB-N in the muscle of fish with treated either shallot or garlic extracts was retained below the level of $25 \mathrm{mg} \mathrm{N} / 100 \mathrm{~g}$ of fish muscle after 5 days of ice storage. The lower TVB$\mathrm{N}$ value of fish with treated either shallot or garlic extracts could be due to the antimicrobial effect of the extracts.

Changes in total viable count (TVC) of round scad with treated shallot extract, garlic extract, and control during ice storage are presented in Figure 6.

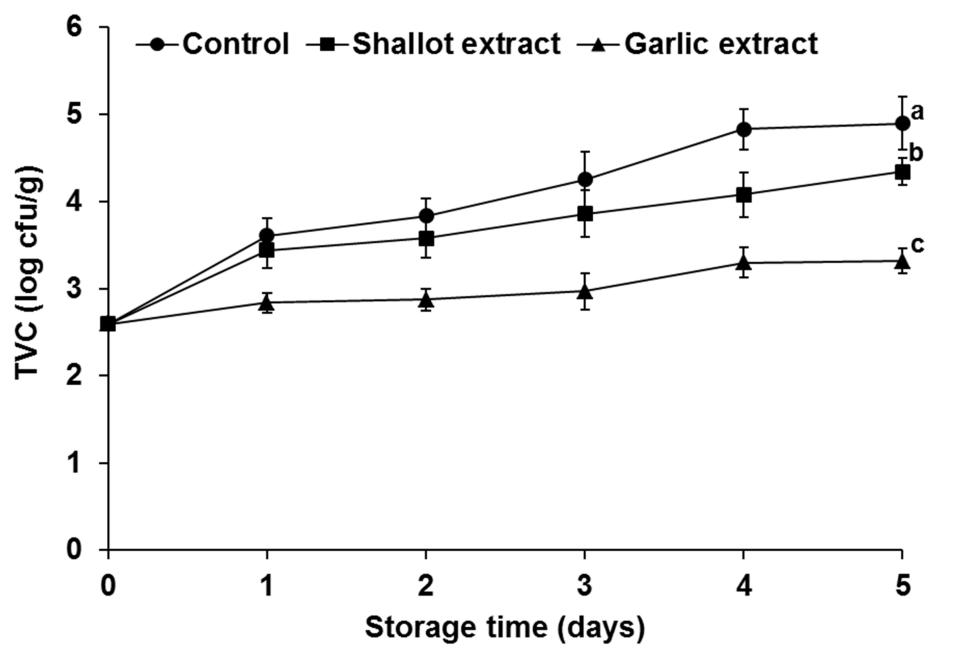

Figure 6. Changes in total viable count (TVC) of round scad during iced storage. ( $\mathbf{a})$, The round scad was immersed in shallot extract; $(\boldsymbol{\Delta})$, The round scad was immersed in garlic extract; $(\bullet)$, The round scad was immersed in distilled water. Data are presented as mean $\pm \operatorname{SD}(\mathrm{n}=3)$. Values with different superscript letters represent a significant difference $(p<0.05)$.

Figure 6 shows that the TVC in all of the round scad increased with storage time. The immersing round scad in either shallot or garlic extracts inhibited bacterial growth in the fish during 5 days of ice storage. The TVC of the fish treated with garlic extract were significantly $(\mathrm{p}<0.05)$ lower than those treated with shallot extract. Fish spoilage is more often characterized by off-odours caused by the metabolism of bacteria. When the number of microorganisms grows to more than $10^{7}-10^{8} \mathrm{cfu} / \mathrm{g}$, significant amounts of volatile sulfur-containing compounds are produced and the spoilage becomes evident (Gram and Huss, 1996; Gram and Dalgaard, 2002). In the present study, the TVC was lower than $10^{6} \mathrm{cfu} / \mathrm{g}$ in all of 
samples after 5 days of ice storage. This result may be due to the scad that was washed with cold tap water prior to treatment in the present case. Inácio et al. (2003) also reported that there was a positive effect of washing with tap water on the quality of whole scad (Trachurus trachurus) and the TVC of whole scad washed with tap water was lower than $10^{6} \mathrm{cfu} / \mathrm{g}$ after 5 days of ice storage.

Changes in sensory scores of round scad with treated shallot extract, garlic extract, and control during ice storage are presented in Figure 7.

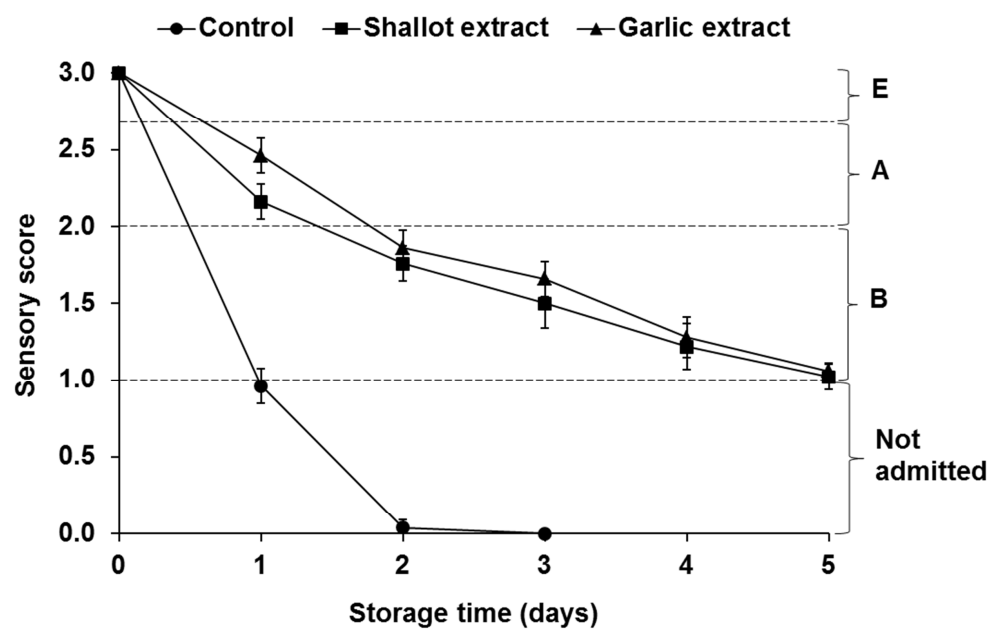

Figure 7. Changes in sensory scores of round scad during iced storage. (घ), The round scad was immersed in shallot extract; $(\boldsymbol{\Delta})$, The round scad was immersed in garlic extract; $(\bullet)$, The round scad was immersed in distilled water. Data are presented as mean $\pm \operatorname{SD}(n=5)$.

Figure 7 shows that the sensory scores of round scad in all samples decreased with storage time. The round scad immersed in either shallot or garlic extracts retained a good quality (A) longer than 1.5 days of iced storage and was accepted for foodgrade after 5 days of iced storage. Contrary to this, round scad of the control group was not accepted for food-grade after only one day under similar storage conditions. In the first-three days of iced storage, the sensory scores of round scad treated with garlic extract were slightly higher $(p<0.05)$ than that of round scad treated with shallot extract. However, there was no significant difference between the sensory scores of round scad treated with shallot extract and round scad treated with garlic extract at the later stage of storage. The appearance of round scad in the first-three days of ice storage as shown in Figure 8. Shallot and garlic flavours of the treated fish were not recognized in this particular experiment. Volatile organosulfur compounds are major responsible for the characteristic flavours of Allium species, including shallot and garlic. However, they are relatively unstable and undergo rapid decomposition to produce lipophilic organosulfides such as diallyl sulfide, diallyl disulfide, and allyl methyl sulfide. The lipophilic organosulfides can be readily oxidized by hydrogen peroxide to form allicin and odourless substances (allyl methyl sufloxide, allyl methyl sulfone, diallyl sulfone) 
(Randle and Lancaster, 2009; Block, 2010; Rao et al., 2015; Scheffler et al., 2016). In this particular case, HPO formed in the fish with treated shallot extract or garlic extract might react with organosulfides of the extracts to form odourless substances. Thus, shallot and garlic flavour intensity of the treated fish decreased with storage time.

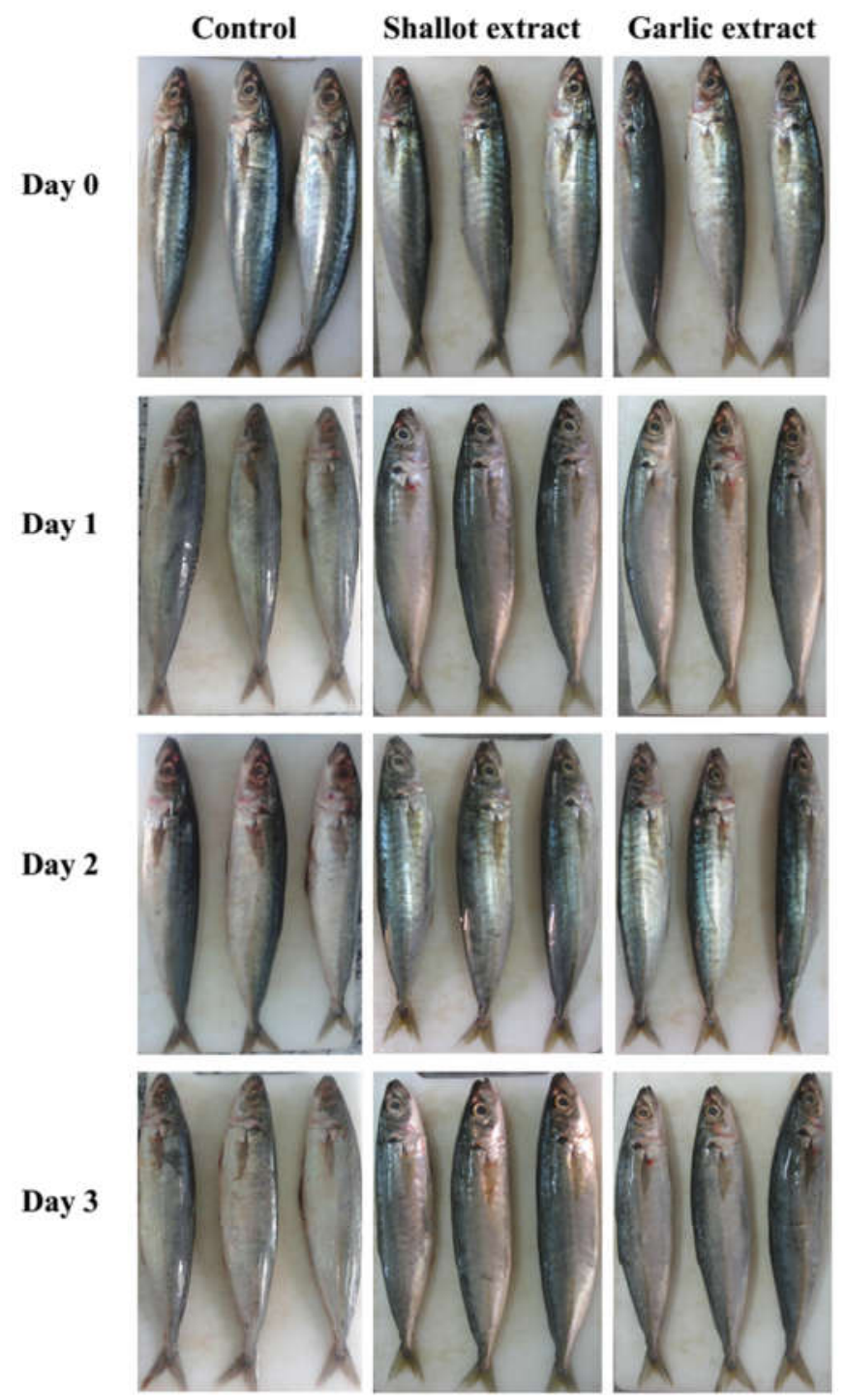

Figure 8. Apparent changes occurred in round scad during ice storage. Shallot extract, the round scad was immersed in shallot extract; Garlic extract, the round scad was immersed in garlic extract; Control, the round scad was immersed in distilled water. 


\section{Conclusions}

The hydrophilic extracts from shallot and garlic exhibited antioxidant and antimicrobial activities in vitro and in post-mortem round scad stored on ice. The immersion of round scad in the shallot or garlic extracts effectively extended their shelf-life. Shallot and garlic bulbs are often used as elementary spices with no known toxic effects. This study clearly showed that the hydrophilic extracts prepared from shallot and garlic bulbs are promising sources of natural preservatives for fish and fish products.

\section{References}

Amin, M., Montazeri, E. A., Mashhadizadeh, M. A., Sheikh, A. F. 2009. Characterization of shallot, an antimicrobial extract of Allium ascalonicum. Pakistan Journal of Medical Sciences, 25(6), 948-952.

Amit, S. K., Uddin, M. M., Rahman, R., Islam, S. M. R., Khan, M. S. 2017. A review on mechanisms and commercial aspects of food preservation and processing. Agriculture and Food Security, 6, 51.

Ankri, S., Mirelman, D. 1999. Antimicrobial properties of allicin from garlic. Microbes and Infection, 1(2), 125-129.

Bao, H. N. D, Loan, T. T., Hien, P. T. 2017. Effects of ultrasound-assisted extraction conditions on antioxidant activity of extracts from onion bulbs (Allium ascalonicum). Journal of Fisheries Science and Technology, 1/2017, 91-98. (in Vietnamese)

Bao, H. N. D., Duong, N. T. H., Hien, P. T. 2014. Fenton reaction applied for determining antioxidative activity. Journal of Fisheries Science and Technology, 3/3014, 9-15. (in Vietnamese)

Bao, H. N. D., Ohshima, T. 2013. Strategies To Minimize Oxidative Deterioration In Aquatic Food Products: Application Of Natural Antioxidants From Edible Mushrooms. In: Lipid Oxidation: Challenges in Food Systems. Logan A., Nienaber U., Pan X., AOCS press, Champaign, IL.

Bao, H. N. D., Ohshima, T. 2014. Strategies to minimize lipid oxidation of aquatic food products post harvest. In: Antioxidants and Functional Components in Aquatic Foods. Kristinsson H. G., John Wiley \& Sons, Ltd.

Beato, V. M., Orgaz, F., Mansilla, F., Montaño, A. 2011. Changes in phenolic compounds in garlic (Allium sativum L.) owing to the cultivar and location of growth. Plant Foods for Human Nutrition, 66(3), 218-223.

Benkeblia, N. 2004. Antimicrobial activity of essential oil extracts of various onions (Allium cepa) and garlic (Allium sativum). LWT - Food Science and Technology, 37(2), 263-268.

Benkeblia, N. 2005. Free-radical scavenging capacity and antioxidant properties of some selected Onions (Allium cepa L.) and garlic (Allium sativum L.) extracts. Brazilian Archives of Biology and Technology, 48(5), 753-759.

Benkeblia, N., Dahmouni, S., Onodera, S., Shiomi, N. 2005. Antimicrobial activity of phenolic compound extracts of various onions (Allium cepa L.) cultivars and garlic (Allium sativum L.). Journal of Food Technology, 3(1), 30-34.

Bisen, P. S., Emerald, M. 2016. Nutritional and therapeutic potential of garlic and onion (Allium sp.). Current Nutrition \& Food Science, 12(3), 190-199. 
Bligh, E. G., Dyer, W. J. 1959. A rapid method of total lipid extraction and purification. Canadian Journal of Biochemistry and Physiology, 37(8), 911-917.

Block, E. 2010. Garlic and Other Alliums - The Lore and The Science. Cambridge, UK: RSC publishing.

Chibane, L. B., Degraeve, P., Ferhout, H., Bouajila, J., Oulahal, N. 2019. Plant antimicrobial polyphenols as potential natural food preservatives. Journal of the Science of Food and Agriculture, 99(4), 1457-1474.

Bozin, B., Mimica-Dukic, N., Samojlik, I., Goran, A., Igic, R. 2008. Phenolics as antioxidants in garlic (Allium sativum L., Alliaceae). Food Chemistry, 111(4), 925929.

Chaithradhyuthi, Gayathri, S., Sowmya, P. S., Shwetha, B. R., Gowri, S., Rama, B. P., Manojkumar, N. H., Raghavendra, R. B. 2009. Evaluation of the antioxidant and antimicrobial properties of some members of Allium. Electronic Journal of Environmental, Agricultural and Food Chemistry, 8(5), 345-350.

Charoenchai, L., Settharaksa, S., Sueree, L., Wunnakup, T., Phetmanee, T., Lukkunaprasit, T., Meksuriyen, D. 2017. Antioxidant, antimicrobial , tyrosinase enzyme inhibition and chemical compositions of shallot extracts. Bulletin of Health, Science and Technology, 15(1), 17-27.

Chemat, F., Vian, M. A., Cravotto, G. 2012. Green extraction of natural products: Concept and principles. International Journal of Molecular Sciences. 13(7), 8615-8627.

Commission Regulation. 2005. Commission Regulation (EC) No 2074/2005 of 5 December 2005, Annex II, Section II, Chapter III Determination of the concentration of TVB-N in fish and fishery products; Official Journal of the European Union.

Connell, J. J. 1990. Methods of Assessing and Selecting for Quality. In: Control of Fish Quality. 4th edn, Oxford: Fishing News Books.

Drozd, M., Thomas, M., Nowak, R. 2011. Determination of phenolic acids in raw garlic (Allium sativum L.) and onion (Allium cepa L.) bulbs. Annales Universitatis Mariae Curie-Sklodowska, Sectio DDD: Pharmacia. XXIV, N 1(14): 121-127.

Fu, H. Y., Shieh, D. E., Ho, C. T. 2002. Antioxidant and free radical scavenging activities of edible mushrooms. Journal of Food Lipids, 9(1), 35-46.

Gokoglu, N. 2019. Novel natural food preservatives and applications in seafood preservation: A review. Journal of the Science of Food and Agriculture, 99(5), 20682077.

Gram, L., Dalgaard, P. (2002). Fish spoilage bacteria - Problems and solutions. Current Opinion in Biotechnology. 13(3), 262-266.

Gram, L., Huss, H. H. 1996. Microbiological spoilage of fish and fish products. International Journal of Food Microbiology. 33(1), 121-137.

Gyawali, R., Hayek, S. A., Ibrahim, S. A. 2015. Plant extracts as antimicrobials in food products: Types. In: Handbook of Natural Antimicrobials for Food Safety and Quality. Taylor T.M., Woodhead Publishing.

Hale, M. B. 1984. Proximate chemical composition and fatty acids of three small coastal pelagic species. Marine Fisheries Review, 46(1), 19-21.

Howgate, P. 2010a. A critical review of total volatile bases and trimethylamine as indices of freshness of fish. part 1. determination. Electronic Journal of Environmental, Agricultural and Food Chemistry, 9(1), 29-57. 
Howgate, P. 2010b. A critical review of total volatile bases and trimethylamine as indices of freshness of fish. part 2. formation of the bases, and application in quality assurance. Electronic Journal of Environmental, Agricultural and Food Chemistry, 9(1), 58-88.

Hoyland, D. V., Taylor, A. J. 1991. A review of the methodology of the 2-thiobarbituric acid test. Food Chemistry, 40(3), 271-291.

Inácio, P., Bernardo, F., Vaz-Pires, P. 2003. Effect of washing with tap and treated seawater on the quality of whole scad (Trachurus trachurus). European Food Research and Technology, 217(5), 406-411.

ISO. 2013. ISO 4833-1: 2013. Microbiology of the food chain - Horizontal method for the enumeration of microorganisms - Part 1: Colony count at 30 degrees $C$ by the pour plate technique.

Kang, M. J., Kang, J. R., Kim, D. G., Shin, J. H. 2018. Chemical characteristics and antioxidant activity of garlic extract from different ethanol solution. Journal of the Korean Society of Food Science and Nutrition, 47(9), 895-903.

Ke, P. J., Nash, D. M., Ackman, R. G. 1976. Quality preservation in frozen mackerel. Canadian Institute of Food Science and Technology Journal, 9(3), 135-138.

Kuley, E., Durmus, M., Balikci, E., Ucar, Y., Regenstein, J. M., Özoğul, F. 2017. Fish spoilage bacterial growth and their biogenic amine accumulation: Inhibitory effects of olive by-products. International Journal of Food Properties, 20(5), 1029-1043.

Leelarungrayub, N., Rattanapanone, V., Chanarat, N., Gebicki, J. M. 2006. Quantitative evaluation of the antioxidant properties of garlic and shallot preparations. Nutrition, 22(3), 266-274.

McDonnell, C., Tiwari, B. K. 2017. Ultrasound: A clean, green extraction technology for bioactives and contaminants. Comprehensive Analytical Chemistry. 76, 111-129.

Mei, J., Ma, X., Xie, J. 2019. Review on natural preservatives for extending fish shelf life. Foods, 8(10), 490.

Metillo, E. B., Aspiras-Eya, A. A. 2014. Fatty acids in six small pelagic fish species and their crustacean prey from the Mindanao Sea, Southern Philippines. Tropical Life Sciences Research, 25(1), 105-115.

Mozin, S., Rosyidi, D., Sjofjan, O., Widodo, E. 2015. The effect of shallot (Allium ascalonicum L.) by-product as an antibacterial and alternative phytobiotic on characteristics of small intestine of broiler. Livestock Research for Rural Development, 27(4), 78.

Nuutila, A. M., Puupponen-Pimiä, R., Aarni, M., Oksman-Caldentey, K. M. 2003. Comparison of antioxidant activities of onion and garlic extracts by inhibition of lipid peroxidation and radical scavenging activity. Food Chemistry. 81(4), 485-493.

Octaviani, M., Fadhli, H., Yuneistya, E. 2019. Antimicrobial activity of ethanol extract of shallot (Allium cepa L.) peels. Pharmaceutical Sciences and Research, 6(1), 62-68.

Odeyemi, O. A., Burke, C. M., Bolch, C. C. J., Stanley, R. 2018. Seafood spoilage microbiota and associated volatile organic compounds at different storage temperatures and packaging conditions. International Journal of Food Microbiology, 280 (2), 87-99.

Olatunde, O. O., Benjakul, S. 2018. Natural preservatives for extending the shelf-life of seafood: A revisit. Comprehensive Reviews in Food Science and Food Safety, 17(6), 
$1595-1612$.

Othman, S. F. C., Kamarudin, K. R., Idid, S. Z. I. S. O., Rehan, A. M., Koya, M. S. 2008. A comparative study on the antioxidant activity in garlic (Allium sativum) and shallot (Allium cepa). In 2nd International Conference on Advancement of Science and Technology (iCAST).

Oyaizu, M. 1986. Studies on products of browning reaction. Antioxidative activities of products of browning reaction prepared from glucosamine. The Japanese Journal of Nutrition and Dietetics, 44(6), 307-315.

Pabón-Baquero, L. C., Otálvaro-Álvarez, Á. M., Fernández, M. R. R., Chaparro-González, M. P. 2018. Plant extracts as antioxidant additives for food industry. In: Antioxidants in Foods and Its Applications. Shalaby E., Azzam G. M., IntechOpen.

Pezeshk, S., Hosseini, H., Rezaei, M., Khaksar, R. 2013. Evaluation of shelf life of live and gutted fish treated with a shallot extract. Journal of Food Processing and Preservation, 37(5), 970-976.

Pezeshk, S., Ojagh, S. M., Alishahi, A. 2015. Effect of plant antioxidant and antimicrobial compounds on the shelf-life of seafood - A review. Czech Journal of Food Sciences, 33(3), 195-203.

Pezeshk, S., Rezaei, M., Hosseini, H. 2011. Effects of turmeric, shallot extracts, and their combination on quality characteristics of vacuum-packaged rainbow trout stored at $4 \pm 1{ }^{\circ} \mathrm{C}$. Journal of Food Science, 76(6), M387-M391.

Phuong, N. T. Y., Bao, H. N. D. 2020. Study on green extraction of antioxidants from garlic bulbs (Allium sativum L.). Can Tho University Journal of Science. Part B: Agriculture, Fisheries and Biotechnology, 56(1B), 124-135. (in Vietnamese)

Pudzianowska, M., Gajewski, M., Przybył, J. L., Buraczyńska, A., Gaczkowska, O., Matuszczak, M., Dziechciarska, M. 2012. Influence of storage conditions on flavonoids content and antioxidant activity of selected shallot (Allium cepa Var. ascalonicum Backer) hybrid cultivars. Vegetable Crops Research Bulletin, 77, 101111.

Raeisi, S., Sharifi-Rad, M., Quek, S. Y., Shabanpour, B., Sharifi-Rad, J. 2016. Evaluation of antioxidant and antimicrobial effects of shallot (Allium ascalonicum L.) fruit and ajwain (Trachyspermum ammi (L.) Sprague) seed extracts in semi-fried coated rainbow trout (Oncorhynchus mykiss) fillets for shelf-life extension. LWT - Food Science and Technology, 65, 112-121.

Raharjo, S., Sofos, J. N., Schmidt, G. R. 1993. Solid-phase acid extraction improves thiobarbituric acid method to determine lipid oxidation. Journal of Food Science, 58(4), 921-924.

Rahman, M. M., Fazlic, V., Saad, N. W. 2012. Antioxidant properties of raw garlic (Allium sativum) extract. International Food Research Journal, 19(2), 589-591.

Rahman, M. S. 2007. Allicin and other functional active components in garlic: Health benefits and bioavailability. International Journal of Food Properties. 10(2), 245268.

Randle, W. M., Lancaster, J. E. 2009. Sulphur compounds in alliums in relation to flavour quality. In: Allium crop science: recent advances. Rabinowitch, H. D., Currah, L., CABI.

Rao, P., Midde, N., Miller, D., Chauhan, S., Kumar, A., Kumar, S. 2015. Diallyl sulfide: Potential use in novel therapeutic interventions in alcohol, drugs, and disease 
mediated cellular toxicity by targeting cytochrome P450 2E1. Current Drug Metabolism, 16(6), 486-503.

Saenthaweesuk, S., Jitvaropas, R., Somparn, N., Thuppia, A. 2015. An investigation of antimicrobial and wound healing potential of Allium ascalonicum Linn. Journal of the Medical Association of Thailand. 98(Supp1 2), S22-27.

Santhosha, S. G., Jamuna, P., Prabhavathi, S. N. 2013. Bioactive components of garlic and their physiological role in health maintenance: A review. Food Bioscience, 3, 59-74.

Scheffler, L., Sauermann, Y., Heinlein, A., Sharapa, C., Buettner, A. 2016. Detection of volatile metabolites derived from garlic (Allium sativum) in human urine. Metabolites, 6(4), 43.

Shahidi, F., Ambigaipalan, P. 2018. Omega-3 polyunsaturated fatty acids and their health benefits. Annual Review of Food Science and Technology, 9(1), 345-381.

Shantha, N. C., \& Decker, E. A. 1994. Rapid, sensitive, iron-based spectrophotometric methods for determination of peroxide values of food lipids. Journal of $A O A C$ International. 77(2), 421-424.

Sohn, J. H., Taki, Y., Ushido, H., Kohata, T., Shioya, I., Oshima, T. 2005. Lipid oxidations in ordinary and dark muscles of fish: Influences on rancid off-odor development and color darkening of yellowtail flesh during ice storage. Journal of Food Science, 70(7), S490-S496.

Sultanbawa, Y. 2014. Plant extracts as natural antimicrobials in food preservation. In: Microbial Food Safety and Preservation Techniques. Rai V. R., Bai J. A., CRC Press.

Thuy, N. M., Tuyen, N. T. M., Cuong, N. P., Huyen, L. T. N., Phuong, N. P., Nguyen, L. T. T., Kim, J. H., Thu, N.T., Tai, N. V. 2020. Identification and extraction method of quercetin from flesh and skin of shallot (Allium ascalonicum) cultivated in Soc Trang Province, Vietnam. Food Research, 4(2), 358-365.

Tiwari, B. K. 2015. Ultrasound: A clean, green extraction technology. TrAC - Trends in Analytical Chemistry. 71, 100-109.

Uchiyama, M., Mihara, M. 1978. Determination of malonaldehyde precursor in tissues by thiobarbituric acid test. Analytical Biochemistry, 86(1), 271-278.

Viswanathan, V., Phadatare, A. G., Mukne, A. 2012. Antimycobacterial and antibacterial activity of Allium sativum bulbs. Hamdan Medical Journal, 73(3), 256-261.

Weng, C. J., Yen, G. C. 2015. Natural plant extracts as antioxidants for food preservation. In: Handbook of Antioxidants for Food Preservation. Shahidi F., Woodhead Publishing.

Zeng, Y., Li, Y., Yang, J., Pu, X., Du, J., Yang, X., Yang, T. Yang, S. 2017. Therapeutic role of functional components in alliums for preventive chronic disease in human being. Evidence-Based Complementary and Alternative Medicine, 2017, ID 9402849, 13 . 